\title{
Multiple Gastric Carcinomas Associated with Potter Type III Cystic Disease
}

\author{
Kenji Mimatsu ${ }^{a}$ Takatsugu Oida ${ }^{a}$ Atsushi Kawasaki ${ }^{a}$ \\ Hisao Kano ${ }^{a}$ Kazutoshi Kida ${ }^{a}$ Nobutada Fukino $^{a}$ \\ Youichi Kuboi $^{\mathrm{a}}$ Sadao Amano ${ }^{\mathrm{b}}$ \\ aDepartment of Surgery, Social Insurance Yokohama Central Hospital, Yokahama,

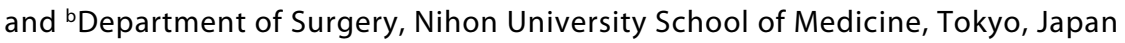

\section{Key Words}

Gastric carcinoma · Polycystic disease · Polycystic liver and kidney disease

\begin{abstract}
We report a case of multiple gastric carcinomas associated with Potter type III cystic disease of the liver, mesenterium and kidney. A 65-year-old man with chronic renal failure due to polycystic kidneys and under hemodialysis treatment 3 times a week for 2 years was admitted to our hospital because of anemia. He stated that his sister had suffered from polycystic kidney disease. Gastrointestinal fiberscopy showed two lesions in the lesser curvature in the lower portion of the stomach, and histopathological analysis of the gastric tumor biopsies revealed that one of the tumors was a papillary adenocarcinoma and the other a poorly differentiated adenocarcinoma. Helicobacter pylori infection was not detected in the stomach mucosa. Abdominal computed tomography scan revealed polycystic lesions in the liver, mesenterium and both kidneys. These imaging findings and family history suggested that the patient suffered from multiple gastric carcinomas associated with Potter type III cystic disease of the liver, mesenterium and kidney. Reports on the association of malignant neoplasm with Potter type III cystic disease are extremely rare. Especially, no case of the association of gastric carcinoma with Potter type III cystic disease of the liver and kidney has been described previously. This is a first report of the association of gastric carcinoma with Potter type III cystic disease. We also review reports of other malignant neoplasms associated with polycystic disease.
\end{abstract}




\section{Introduction}

Polycystic liver disease is a condition characterized by the presence of multiple cysts in the liver, which may be inherited or sporadic, and most cases of adult polycystic liver disease (APLD) are related to autosomal dominant polycystic kidney disease (ADPKD). In 1964, Osathanondh and Potter [1] classified polycystic kidney into three types. Potter type III cystic disease corresponds to the adult type of polycystic kidney. There have been some reports, till date, that describe the association of malignant neoplasms with Potter type III cystic disease of the liver and kidney [2-8]; however, most of these describe pancreatic and hepatobiliary neoplasms arising in patients with polycystic liver and kidney diseases including ADPKD, and no report has described the association of gastric carcinoma with Potter type III cystic disease of the liver and kidney. This is the first case report of multiple gastric carcinomas associated with Potter type III cystic disease of the liver, mesenterium and kidney. Although it is unclear whether the development of multiple gastric carcinomas is directly associated with the pathogenesis of multiple cysts in the liver, mesenterium and kidney, this case provides a perspective for etiology of gastric carcinoma with polycystic disease.

\section{Case Report}

A 65-year-old man was admitted to our hospital because of anemia. He had been receiving hemodialysis treatment 3 times a week for 2 years because of chronic renal failure due to polycystic kidneys. He stated that his sister had suffered from polycystic kidney disease. Physical examination on admission revealed distended abdomen due to polycystic disease. Laboratory examination revealed hemoglobinemia $(8.5 \mathrm{~g} / \mathrm{dl})$. The result of the diagnostic tests for hepatitis B and $\mathrm{C}$ was negative. The patient had high serum levels of carcinoembryonic antigen $(7.9 \mathrm{ng} / \mathrm{ml})$ and carbohydrate antigen $19-9$ (202 $\mathrm{mg} / \mathrm{dl})$. An abdominal computed tomography scan showed multiple cysts in the liver and cystic lesions on both sides in the kidney and mesenterium (fig. 1). These findings suggested that he suffered from polycystic disease of the liver and kidney. Gastrointestinal fiberscopy showed the presence of two ulcerated lesions in the lesser curvature in the middle and lower portions of the stomach. Histopathological analysis of the gastric tumor biopsy specimens revealed papillary adenocarcinoma in one tumor and poorly differentiated adenocarcinoma in another. Distal gastrectomy with lymph node dissection was performed, and the gastric tumors were surgically diagnosed to be T2N1M0, stage II, according to the TNM classification for gastric carcinoma. Operative examination confirmed the presence of multiple cysts in the liver ( $\underline{\text { fig. } 2 a)}$ ) and on both sides in the kidney and mesenterium (fig. 2b).

Macroscopic examination showed that two tumors of type II were present in the middle and lower portions of the stomach (fig. $3 \mathrm{a}$ ). On the basis of a histopathological examination, the distal lesion was diagnosed as a poorly differentiated adenocarcinoma $(38 \times 39 \times 6 \mathrm{~mm})$ within the muscularis propria, with marked lymphatic invasion (ly2) and vascular invasion (v2) (fig. 3b); the lesion on the proximal side was diagnosed as a papillary adenocarcinoma $(58 \times 47 \times 6 \mathrm{~mm})$ within the submucosal layer, with marked lymphatic invasion (ly2) and vascular invasion (v1) (fig. 3c). Normal gastric mucosa was observed between the tumors. Lymph node metastases had occurred around the right gastroepiploic artery and right gastric artery. Helicobacter pylori infection was not detected in the stomach mucosa.

\section{Discussion}

ADPKD is the most common of all inherited renal cystic diseases and has various external manifestations, including cysts in the pancreas, seminal vesicles, arachnoid membrane, and liver [9]. Many classifications for cystic diseases of the kidney have been proposed. The most accepted among them is the Osathanondh and Potter system that was 
established in 1964, according to which polycystic kidneys are classified into three types [1]. Potter type III cystic disease involves one or more of several abnormalities. The cysts may be present in any portion of the nephron or tubule, but they are most commonly found in Bowman's space and the angle of the loop of Henle. In the older classification, Potter type III cystic disease was considered to represent adult-type polycystic disease of the kidney. In 1972, Hatfield and Pfister pathologically examined 399 patients with multiple cysts in both kidneys [10]. They also observed cysts in the liver and/or pancreas in 58 of these patients; hence, they described this condition as Potter type III polycystic disease. In the present case, computed tomography and ultrasonography scans showed multiple renal and hepatic cysts in addition to multiple cysts in the mesenterium. Therefore, according to Hatfield and Pfister's criteria [10], we considered that this case of association of APLD with multiple renal cysts could be classified as Potter type III cystic disease. The patient stated that his sister had suffered from polycystic kidney disease; however, we could not confirm the presence of a family history of polycystic kidney disease because his sister had been out of contact for long. In the absence of a family history of ADPKD, bilateral multiple renal cysts with hepatic cysts, together with the absence of other manifestations suggesting a different renal cystic disease, provide evidence for diagnosis [9]. In these instances, molecular genetic analysis is required. A family history, however, may be absent in $20-40 \%$ of new patients in whom the diagnosis of ADPKD first is suspected from imaging studies, which can be due to a de novo mutation of $P K D-1$ or $P K D-2$ genes [11]. Although we could not confirm the mutation of $P K D-1$ or $P K D-2$ in this case, family history, clinical findings and imaging studies suggested that the patient suffered from ADPKD.

Reports on the association of malignant neoplasm with APLD and ADPKD (Potter type III cystic disease) are extremely rare. To our knowledge, only 8 such cases have been reported in the English language literature (table 1) [2-8]. Till date, most cases of neoplasms associated with polycystic disease of the liver and kidney have been reported as either pancreatic or hepatobiliary neoplasms, namely 5 cases of pancreatic neoplasms and 3 cases of cholangiocarcinoma. Since 5 of these cases were pancreatic neoplasms, we think that ADPKD has some genetic influence on the development of pancreatic neoplasms. Aziz et al. [12] reported 2 patients from the same family (a brother and a sister) with ADPKD who developed adenocarcinoma of the gastroesophageal junction; however, these patients did not have cysts in the liver or other organs except for the kidney. In the present case, although a detailed family history could not be obtained, multiple cysts were observed in the liver, both kidneys, and mesenterium.

ADPKD is caused by defects in PKD-1 or PKD-2 [13]. These genes encode a member of the polycystin protein family, which is an integral membrane protein that functions as a regulator of calcium-permeable cation channels and intracellular calcium homoeostasis [14]. Some studies have described an association between the $P K D$ genes and cancer cells; polycystin-1, encoded by $P K D-1$, was reported to induce apoptosis and cell cycle arrest in the G0/G1 phase in cancer cells [14]. Moreover, $P K D-1$ inhibits cancer cell migration and invasion and may be considered a new member of the tumor suppressor family of genes [15]. These molecular studies suggested that $P K D$ genes inhibit cancer progression. Therefore, ADPKD, which is caused by defective $P K D-1$ and $P K D-2$, may be a carcinogenic condition. In addition, mutations in two genes, namely $P R K S C H$ (which codes for hepatocystin) and SEC63, have been found to cause APLD. However, 


\begin{tabular}{|c|c|c|c|}
\hline $\begin{array}{r}\text { Case Reports in } \\
\text { Gastroenterology }\end{array}$ & $\begin{array}{l}\text { Case Rep Gastroenterol 2011;5:590-596 } \\
\text { DOI: 10.1159/000329179 }\end{array}$ & $\begin{array}{l}\text { Published online: } \\
\text { October 7, } 2011\end{array}$ & $\begin{array}{l}\text { (c) } 2011 \text { S. Karger AG, Basel } \\
\text { ISSN 1662-0631 } \\
\text { www.karger.com/crg }\end{array}$ \\
\hline
\end{tabular}

as mutations in these genes have not been found in all families, undiscovered genes responsible for causing APLD probably still exist [13].

Although it is unclear whether the development of multiple gastric carcinomas is directly associated with the pathogenesis of cysts in the liver, mesenterium and kidney, the present case demonstrates that gastric carcinoma can be an external complication in patients with polycystic disease.

\section{Disclosure Statement}

None of the authors has any conflict of interest.

Table 1. Malignant neoplasms associated with polycystic disease of the liver and kidney

\begin{tabular}{|c|c|c|c|c|c|c|c|c|c|c|}
\hline Case & $\begin{array}{l}\text { Refer- } \\
\text { ence }\end{array}$ & $\begin{array}{l}\text { First } \\
\text { author }\end{array}$ & Year & Age & Sex & $\begin{array}{l}\text { Family } \\
\text { history }\end{array}$ & Location of cyst & $\begin{array}{l}\text { Hemo- } \\
\text { dialysis }\end{array}$ & Neoplasms & $\begin{array}{l}\text { Treatment for } \\
\text { neoplasms }\end{array}$ \\
\hline 1 & 2 & Cryer & 1977 & 66 & $\mathrm{~F}$ & PKD & kidney/liver & ND & panc. adenocarcinoma & operation \\
\hline 2 & 3 & Landais & 1984 & 52 & $\mathrm{~F}$ & ND & kidney/liver & done & chorangiocarcinoma & none \\
\hline 3 & 3 & Landais & 1984 & 56 & M & PKD & kidney/liver & done & chorangiocarcinoma & none \\
\hline 4 & 4 & $\mathrm{Niv}$ & 1997 & 68 & M & PKD & kidney/liver & not done & panc. cystadenocarcinoma & none \\
\hline 5 & 5 & Sakurai & 2001 & 63 & $\mathrm{M}$ & PKD/PLD & kidney/liver & not done & panc. ductal adenocarcinoma & none \\
\hline 6 & 6 & Sasaki & 2002 & 60 & $\mathrm{M}$ & PKD & kidney/liver & done & IHCC & none \\
\hline 7 & 7 & Naitou & 2005 & 43 & M & $\mathrm{PKD}$ & kidney/liver/panc. & ND & IPMT & operation (PD) \\
\hline 8 & 8 & Sato & 2009 & 63 & M & none & kidney/liver/panc. & not done & IPMN & operation (PD) \\
\hline 9 & o.c. & Mimatsu & 2011 & 65 & M & ND & kidney/liver/mesen. & done & multiple gastric carcinomas & operation $(\mathrm{G})$ \\
\hline
\end{tabular}

$\mathrm{G}=$ Gastrectomy; IHCC = intrahepatic cholangiocarcinoma; IPMN = intraductal papillary mucinous neoplasm; IPMT = intraductal papillary mucinous tumor; mesen. $=$ mesenterium; $\mathrm{ND}=$ not described; o.c. = our case; panc. = pancreas; $\mathrm{PD}=$ pancreaticoduodenectomy; $\mathrm{PKD}=$ polycystic kidney disease; PLD = polycystic liver disease. 


\begin{tabular}{r|l|l|l} 
Case Reports in & $\begin{array}{l}\text { Case Rep Gastroenterol 2011;5:590-596 } \\
\text { DOl: 10.1159/000329179 }\end{array}$ & $\begin{array}{l}\text { Published online: } \\
\text { October 7, 2011 }\end{array}$ & $\begin{array}{l}\text { O 2011 S. Karger AG, Basel } \\
\text { ISSN 1662-0631 } \\
\text { www.karger.com/crg }\end{array}$ \\
\hline
\end{tabular}
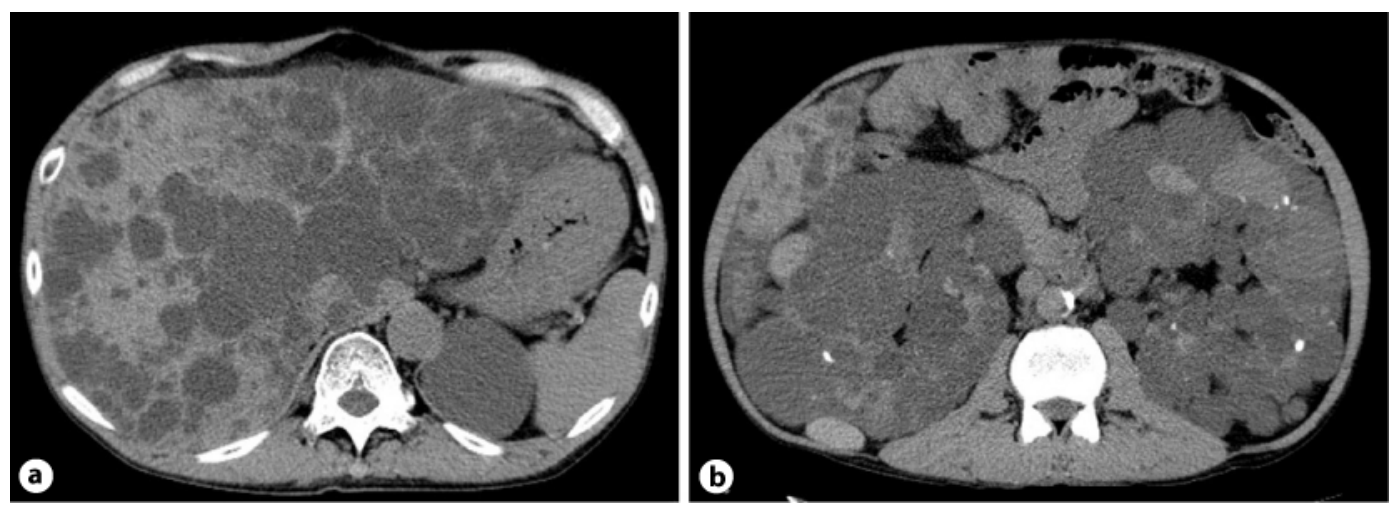

Fig. 1. Abdominal computed tomography scan showed multiple cysts in the liver (a) and cystic lesions on both sides in the kidney (b).
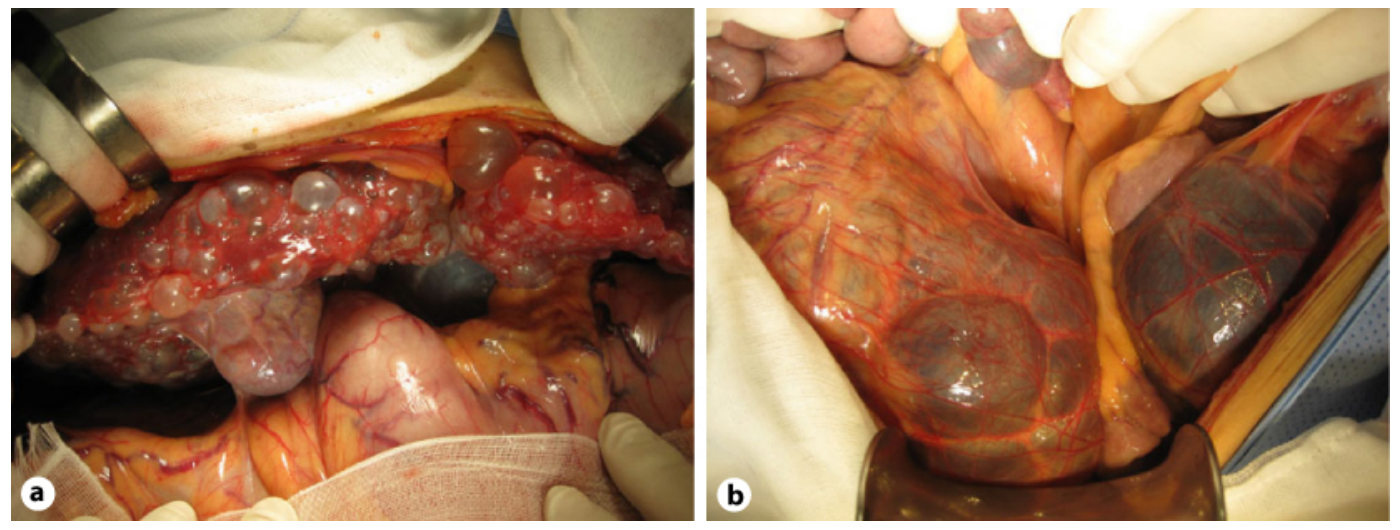

Fig. 2. Operative findings showed the presence of multiple cysts in the liver (a) and mesenterium (b). 


\begin{tabular}{r|l|l|l}
$\begin{array}{r}\text { Case Reports in } \\
\text { Gastroenterology }\end{array}$ & $\begin{array}{l}\text { Case Rep Gastroenterol 2011;5:590-596 } \\
\text { DOl: 10.1159/000329179 }\end{array}$ & $\begin{array}{l}\text { Published online: } \\
\text { October 7, 2011 }\end{array}$ & $\begin{array}{l}\text { O 2011 S. Karger AG, Basel } \\
\text { ISSN 1662-0631 } \\
\text { www.karger.com/crg }\end{array}$ \\
\hline
\end{tabular}

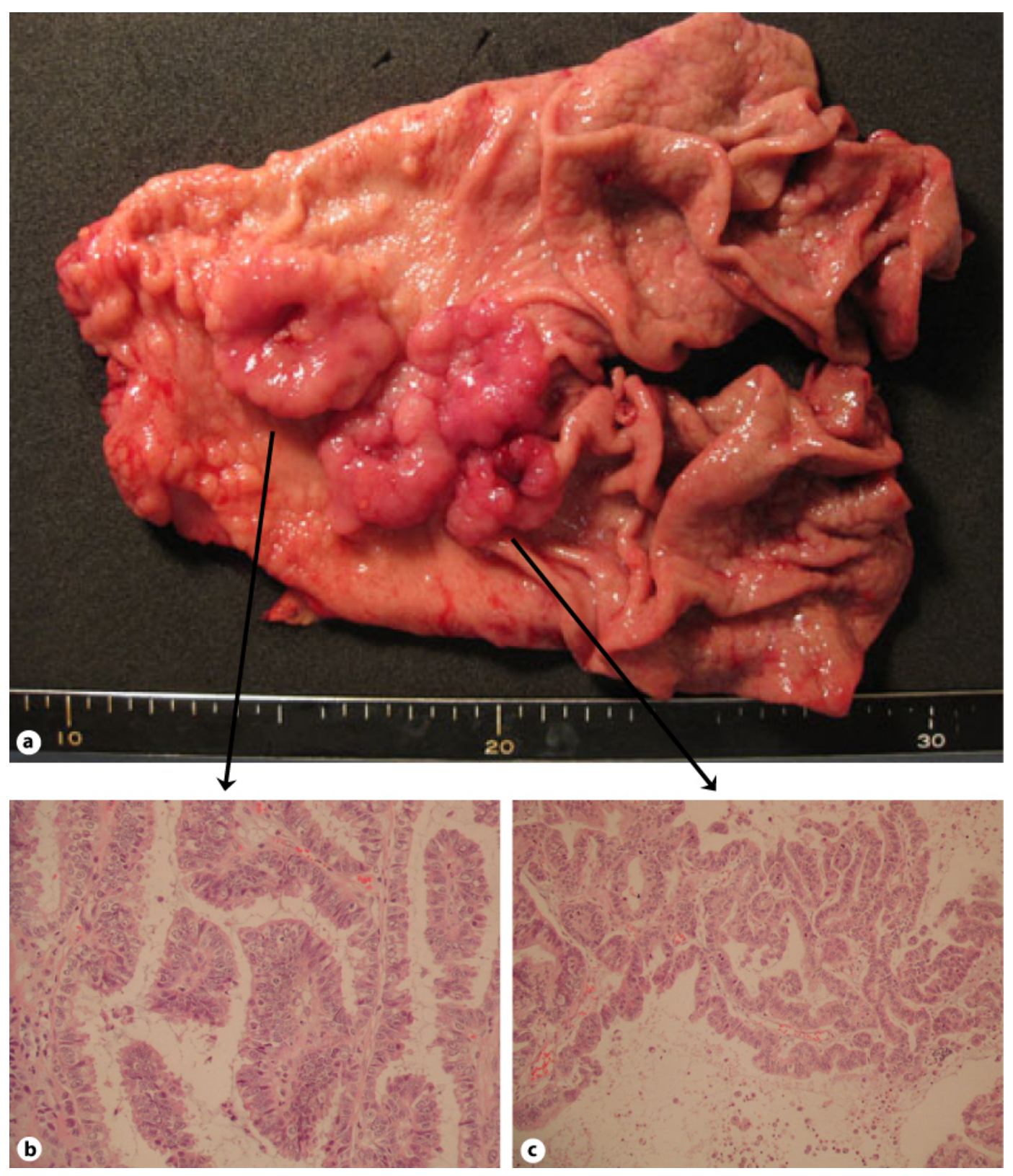

Fig. 3. Macroscopic findings showed that two tumors of type II were present in the antral stomach. Normal gastric mucosa was observed between the tumors (a). Histopathological findings showed poorly differentiated adenocarcinoma in the distal tumor $(\mathbf{b})$ and papillary adenocarcinoma in the proximal tumor (c). HE; $\times 100$. 


\begin{tabular}{|c|c|c|c|}
\hline $\begin{array}{r}\text { Case Reports in } \\
\text { Gastroenterology }\end{array}$ & $\begin{array}{l}\text { Case Rep Gastroenterol 2011;5:590-596 } \\
\text { DOI: } 10.1159 / 000329179\end{array}$ & $\begin{array}{l}\text { Published online: } \\
\text { October 7, } 2011\end{array}$ & $\begin{array}{l}\text { @ } 2011 \text { S. Karger AG, Basel } \\
\text { ISSN 1662-0631 } \\
\text { www.karger.com/crg }\end{array}$ \\
\hline
\end{tabular}

\section{References}

1 Osathanondh V, Potter EL: Pathogenesis of polycystic kidneys: historical survey. Arch Pathol 1964;77:459-512.

$\checkmark 2$ Cryer PE, Kissane JM: Obstructive jaundice in a patient with polycystic disease. Am J Med 1977;62:616-626.

-3 Landais P, Grunfeld JP, Droz D, Drueke T, Albouze G, Gogusev J, Chauveau D, Moynot A: Cholangiocellular carcinoma in polycystic kidney and liver disease. Arch Intern Med 1984;144:2274-2276.

- Niv Y, Turani C, Kahan E, Fraser GM: Association between pancreatic cystadenocarcinoma, malignant liver cysts, and polycystic disease of the kidney. Gastroenterology 1997;112:2104-2107.

5 Sakurai Y, Shoji M, Matsubara T, Ochiai M, Funabiki T, Urano M, Mizoguchi Y, Fuwa N: Pancreatic ductal adenocarcinoma associated with Potter type III cystic disease. J Gastroenterol 2001;36:422-428.

-6 Sasaki M, Katayanagi K, Watanabe K, Takasawa K, Nakamura Y: Intrahepatic cholangiocarcinoma arising in autosomal dominant polycystic kidney disease. Virchows Arch 2002;441:98-100.

7 Naitou H, Shoji H, Ishikawa I, Watanabe R, Furuta Y, Tomozawa S, Igarashi H, Shinozaki S, Katsura H, Onozato R, Kudoh M: Intraductal papillary mucinous tumor of the pancreas associated with autosomal dominant polycystic disease. J Gastrointest Surg 2005;9:843-845.

8 Sato Y, Mukai M, Sasaki M, Kitano A, Yoneda N, Kobayashi D, Imamura Y, Nakanuma Y: Intraductal papillary-mucinous neoplasm of the pancreas associated with polycystic liver and kidney disease. Pathol Int 2009;59:201-204.

-9 Torres VE, Harris PC, Prison Y: Autosomal dominant polycystic kidney disease. Lancet 2007;369:1287-1301.

10 Hatfield PM, Pfister RC: Adult polycystic disease of the kidneys (Potter type 3). JAMA 1972;222:1527-1531.

11 Pei Y: Diagnostic approach in autosomal dominant polycystic kidney disease. Clin J Am Soc Nephrol 2006;1:1108-1114.

12 Aziz SA, Ahmad M, Shah A: Carcinoma of the gastroesophageal junction associated with adult polycystic kidney disease. Nephron 1998;79:362-363.

13 Tahvahainen E, Tahvahainen P, Kaariainen H, Hockerstedt K: Polycystic liver and kidney disease. Ann Med 2005;37:546-555.

14 Zheng R, Zhang Z, Lv X, Fan J, Chen Y, Wang Y, Tan R, Liu Y, Zhou Q: Polycystin-1 induced apoptosis and cell cycle arrest in G0/G1 phase in cancer cells. Cell Biol Int 2008;32:427-435.

15 Zhang K, Ye C, Zhou Q, Zheng R, Lv X, Chen Y, Hu Z, Guo H, Zhang Z, Wang Y, Tan R, Liu Y: PKD1 inhibits cancer cells migration and invasion via Wnt signaling pathway in vitro. Cell Biochem Funct 2007;25:767-774. 